Progress in Human Geography

\title{
Geographies of Conservation III: Nature's Spaces
}

\author{
W.M. Adams, \\ Department of Geograpjy, \\ University of Cambridge, \\ CB2 3EN, UK \\ Wa12@cam.ac.uk
}

\begin{abstract}
There is a rich literature by geographers on the spatial imagination and ambition of conservation, and particularly the long-established strategy of creating protected areas such as national parks. This report highlights five ways in which the spatial ambitions, imaginations and practices of conservation are changing. First, appetite for the expansion of protected areas continues to grow, with proposals for marine reserves and up to half of the earth under protection. Second, substantial intensification of agriculture is proposed to free up land for such expansion, a policy of land sparing. Third, areas being protected areas are increasingly privately owned, and conservation is serving as a powerful form of legitimisation of large-scale private landholding. Fourth, in many countries conservation management is being extended beyond formal protected areas in mosaics of public, private and community land. Fifth, the political and material technologies used to secure conservation territories, like the extension of these territories themselves, raise urgent political ecological questions. Conservation governance physical marks spaces for nature, but also constructs and polices ideas about both nature and society in profound ways, which often go unremarked by conservationists themselves.
\end{abstract}

\section{Keywords:}

conservation, environmentality, green-grabbing, half earth, land sharing, land sparing, national parks, private protected areas, rewilding, territorialisation 
'Human life and the wild life must be separated permanently and completely. So long as man and animals live together there will always be trouble' (Hingston 1931, p 406)

\section{Conservation spatiality}

Geographers have long recognised by that conservation, as a social and political practice, is fundamentally spatial (e.g. Tunbridge 1978, Zimmerer 2000, 2006). Its main strategy is the demarcation of spaces as protected areas within which rules control what humans (and non-humans) do.

The conventional account of conservation's territorialization is that it spread with modern state governance, a by-product of regimes of survey and partition under imperial and later national regimes of statehood (Gissibl et al. 2012). The literature has focused particularly on national parks, with their potent links to ideologies of nation, nature and civilization (Sheail 2010, Gissibl et al. 2012). The establishment of protected areas are typically seen to have involved the imposition of alien (Western) ideas and conservation rules, in various combinations of well-meaning ignorance or calculated injustice, particularly under colonial regimes (e.g. Ranger 1999, Garland 2008). The so-called 'Yellowstone model', involving central state designation of vast areas of scenically monumental land, removal of indigenous people, and development for tourism (Runte 1987, Jacoby 2001) is widely used as shorthand for a standardized explanatory frame for conservation history.

However, protected area histories show diversity in conservation spatial practices. The title 'national park' may suggest a single idea, but different countries adopted very different approaches (Gissibl et al. 2012). The 'Yellowstone model' was more varied than is commonly assumed, and evolved even in Yellowstone itself (Jones 2012). Thus Mexico created 40 national parks in the 1930s primarily for public recreation (Wakild 2012), while across Europe, ideas of 'wilderness' were less important, and the notion of 'frontier' meaningless: different protected area models 
emerged in, for example, Switzerland (Kupper 2012) and the UK (Reynolds 2017) and the Netherlands (van der Windt 2012).

As in history, so in the present day. Conservation is understood to be profoundly neoliberal in many respects (Igoe et al. 2010, Büscher et al. 2012, Adams et al. 2014). Yet as it grows in power and its ambition to influence land use on a global scale, it is important to recognise the complexity of the ideologies that drive it (e.g. Blanchard et al. 2016, Holmes et al. 2017) and the diversity of its spatial expressions. Here, I draw attention to five connected ways in which the spatial ambitions, imaginations and practices of conservation are changing.

\section{More space for nature}

The first and most basic observation about conservation spaces is that ambition to expand them is still growing. Protected areas are universally regarded as an essential (if insufficient) means to sustain species, ecosystems, ecological processes, and evolutionary potential into the future (Wuerthner et al. 2015). Conservationists remain focused on ideas of 'pristine' nature or 'wilderness', even to the extent of trying to map its extent (Watson et al. 2018).

Over 20 million $\mathrm{km}^{2}$, (14.9\% of the earth's land surface) lies within 238,563 internationally recognised protected areas (UNEP-WCMC et al. 2018). In addition, marine protected areas cover over 6 million $\mathrm{km}^{2}$ ( $7.3 \%$ of the world's oceans). This area is set to rise rapidly. Signatories to the 1993 Convention on Biological Diversity (CBD) approved a Strategic Plan for Biodiversity in 2010 at Aichi in Japan. This included the target for protected areas to be extended to at least 17 per cent of terrestrial and inland water and 10\% of oceans by 2020 (UNEP-WCMC et al. 2018). Even more ambitious targets are being proposed for the period 2020-2050, aiming not only to halt biodiversity loss but also to promote recovery (Mace et al. 2018).

Conservation proposals for protected area expansion show that non-human life is still thought about primarily as national, 'a ward of the state' (Neumann 2004, p. 212). However, the CBD plan reflects the emergence of an international conservation regime to drive national government decision-making. There is also growing 
attention to the global commons, for example Areas Beyond National Jurisdiction (ABNJs) in the open ocean (of which only just over 1 per cent is currently protected, UNEP-WCMC et al. 2018).

Conservation ambitions reach far beyond present levels of land control. The 'Nature Needs Half' (NNH) initiative, launched in 2009, calls for protection of $50 \%$ of the planet by 2030 (Nature Needs Half 2019). Noss et al. (2012) reject the Aichi targets as unscientific, and suggest that the larger goal is scientifically defensible. Dinersein et al. (2017, p. 535) analyse the world in terms of its 846 global 'ecoregions', and argue that the target is attainable, although it may require what they call 'intensive efforts' in some regions (Dinersein et al. 2017).

The social impacts of protected areas (displacement in the form of resettlement or lost livelihoods and associated poverty) have been widely explored in the literature (e.g. Dowie 2009, Brockington and Wilkie 2015, Oldekop et al. 2016). The creation of protected areas is widely framed as an example of 'green-grabbing', the enclosure of land (or sea) for environmental purposes (e.g. Fairhead et al. 2012, 2013, Benjaminsen and Bryceson 2012, Holmes 2014, Bluwstein et al. 2018). The social implications of the extension of conservation jurisdiction on to 'half earth' kind scale are obviously huge (Büscher et al. 2016). The NNH proposal embraces all categories of protected area (including areas with sustainable natural resource use). On the other hand, in a widely publicised book Half Earth, veteran biologist Edward Wilson proposed strict protection, 'setting aside half the planet in reserve' (Wilson 2016, p. 3). Neither proposals pays attention to either social impacts or the metabolism of the world economy or to the social impacts of the extension of conservation jurisdiction with this kind of ambition (Büscher et al. 2016).

\section{Land sparing}

The second way in which conservation's spatial ambition is changing is the aspirations of conservation planners for the way non-conserved land is used. Creating more space for nature clearly has opportunity costs to alternative land uses, and existing land occupiers. Balmford and Green (2017) argue there will only be room for the protection on half of the earth if there are significant changes to the way food is grown on the other half. Data on more than 1,600 species of various taxa on four 
continents shows that most cannot live on farmed land, even agriculture is of low intensity (Balmford et al. 2015). Biodiversity loss (and greenhouse gas emissions) could be reduced (particularly in the tropics) if food production per unit area were increased on existing farmland, rather than allowing agriculture to expand. This would minimize farmland area and spare land for habitat conservation or restoration (Phalan et al. 2016).

To make space for conservation, it is therefore necessary to maximize crop yields on existing farmland using the best available technologies and efficient industrial production (Balmford and Green 2017). A formulaic and reductionist choice is presented between 'land sparing' (setting aside spaces for nature that people cannot enter) and 'land sharing (creating mixed landscapes), and has won considerable international policy traction. It pays no attention to obvious questions about rights to land, the economics of farming enterprises, or the choices of existing landholders. It, like the 'half earth' idea, assumes an overarching global governance framework delivering optimal outcomes for biodiversity futures. The political and social dimensions of such ideas go unremarked by conservation advocates.

\section{Private conservation spaces}

The third dimension of conservation's growing spatial ambition is their embrace of private ownership of conservation spaces. The conventional model of protected areas involved state ownership, as in 'national' parks. However, in many countries, there has been a growth of protected areas created by non-state actors, both private landowners and non-governmental conservation organisations and trusts (Hodge and Adams 2012, Radford 2014).

Private protected areas (PPAs) can be owned by individuals or groups of individuals, by NGOs, corporations (commercial companies or corporations set up by groups of private owners to manage groups of PPAs) or by research or religious entities (Stolton et al. 2014). There has been a sustained effort to fit PPAs into the long-established IUCN classification of protected areas, as a tenure category alongside areas governed by the state, indigenous peoples and local communities, and under shared governance. (Stolton et al. 2014). 
There is, of course, nothing new about private nature reserves. Private aristocratic parks have a long history, and the securing of land through purchase was key strategy for non-governmental conservation organisations in the UK in the Nineteenth and early Twentieth centuries (Adams et al. 2014). Yet large private estates are a growing feature of conservation in many countries as diverse as the UK (Glass et al. 2013, Tree 2018), USA (Kiesecker et al. 2007, White 2012), Kenya (Gallmann 1991), Zimbabwe (Suzuki 2001, Wolmer 2007) or Namibia (Lindsey et al. 2013). Many of these new protected areas involve international ownership. In Chile, for example, the US former entrepreneur Douglas Tompkins purchased property from 1990 to create Parque Pumalin in northern Patagonia, stretching from the Pacific coast to the Argentine border (Holmes 2012, 2015). Private protected areas cover over 2\% of the total surface area of Chile (Holmes 2014).

Elites are powerful shapers of conservation policy, and international conservation NGOs increasingly depend on philanthropic donations, particularly for the establishment of new protected areas through land purchase (Holmes 2010, 2012, Ramutsindela et al. 2011). NGOs (such as US organization The Nature Conservancy) are significant conservation landholders internationally (Pasquini et al. 2011). They also control land they do not own, for example taking over governance of poorly performing state protected areas, as the African Parks Network (formerly African Parks Foundation), does in Africa (Holmes 2012).

Conservation on private land often involves novel collaborative arrangements between private property owners, state agencies and environmentalists, for example through the establishment of land trusts, the sale of conservation easements or covenants (Kiesecker et al. 2007, Logan and Wekerle 2008, Kay 2015). Landowners may have diverse motivations for involvement in land protection, and respond to a variety of incentives (Sorice et al. 2011, Fitzsimons and Wescott 2007). The institutional complexity of the resulting hybrids of state and private and environmental organisation interests can be considerable (Kamal et al. 2015, Hodge and Adams 2014, Adams et al. 2016). 
Privately owned PAs provide a welcoming context for market-based conservation strategies, the commoditization of non-human nature and the accumulation of capital. Fee-paying activities and enterprises (wildlife viewing tourism, or hunting), and the availability of payments for ecosystem services or direct payments for conservation provides revenue streams that support conservation land use. Thus southern Africa has seen the rapid shifts from livestock to wildlife husbandry on private land, with over 9000 wildlife ranches in South Africa alone (Lindsey et al. 2013).

Where the tenure of private land is contested, a shift to conservation as a land use has obvious political dimensions, visible in the farm invasions of Zimbabwe in the early 2000s (Wolmer 2007), or in Kenya (Fox 2018). Although many converted Kenyan ranches are owned by conservation trusts, the image of white landowner as conservationist supports colonial patterns of land ownership (Mbaria and Ogada 2016, Fox 2018).

\section{Land sharing:}

The fourth trend within the expansion of conservation's territorial ambitions is an intensified engagement in landscapes beyond protected areas. Conservation biogeography increasingly emphasises the conservation value of landscape-scale links networks of blocks, connections or 'green infrastructure' (Crooks and Sanjayan 2006). It is widely accepted that biodiversity cannot not be sustained on small preserved habitat 'islands'. Aichi Target 11 emphasises the importance of 'ecologically representative and well-connected systems of protected areas' (UNEPWCMC et al. 2018).

Conservation has therefore increasingly sought to 'scale up' action and secure larger areas for wildlife protection, reaching out beyond protected areas in large-scale conservation or restoration initiatives that connect public reserves with private landholdings. Such initiatives are variously referred to as 'landscape scale conservation' (da Fonseca et al, 2005), 'broad-extent conservation programmes' (Beever et al. 2014), 'multi-tenure reserve networks' (Fitzsimons and Wescott 2005), large-scale conservation networks (Fitzsimons et al. 2013), or 'large-scale conservation areas' or 'networks' (Eigenbrod et al. 2017, Fitzsimons et al. 2013). 
A particular example of this is the creation of trans-boundary (or transfrontier) conservation areas such as 'Peace Parks' (Hughes 2005, King and Wilcox 2008, Lunstrum 2013, Büscher 2013). These are closely linked to aspirations for the development of tourism, and opportunities for market-based conservation and naturebased economic development investment, argued to be the quintessential product of neoliberal conservation strategies (e.g. Büscher 2013)

However, while there is some consensus amongst ecologists on the desirability of large-scale conservation, the institutional model to support this is less clearly established. Conservation payments, for example from agri-environment schemes, can be deployed to encourage nature-friendly farming practices, or to compensate for costs of conservation activities undertaken by the landowner, although the costeffectiveness of such schemes in biodiversity terms is often limited, and also not systematically monitored (Ansell et al. 2016).

In Europe, an important element within conservation's hunger for larger landscapes turns on the concept of 'rewilding' (e.g. Monbiot 2013). The concept of rewilding is highly diverse, well beyond its roots in the USA (Jorgenson 2015, Lorimer et al. 2015, Pettorelli et al. 2017). Interest in 'rewilding' over large areas has grown in Europe, with dedicated organisations to promote it (notably Rewilding Europe, whose website declares 'a new approach to European conservation', https://rewildingeurope.com/). Wild carnivores (e.g. wolf and brown bear) are spreading under their own volition across Europe (López-Bao et al. 2017), a form of spontaneous 'rewilding' that can be a significant source of conflict between conservationists, landowners and recreational users (e.g. Buller 2008), particularly where conservationists seek to occupy landscapes emptied by rural economic decline and depopulation (Navarro and Pereira 2012). New proposals to reintroduce carnivores in landscapes used for livestock keeping, walking or hunting in the UK (where even the reintroduction of the European beaver has been difficult, c.f. Gaywood 2017) inevitably create concern. Thus in Mid Wales (UK), the idea of 'wild nature', so appealing to conservationists, suggests to local landowners cultural insensitivity, if not colonialism (Wynne-Jones et al. 2018). 
In the developing world, where land tenure is often far less secure, large areas for conservation are often imposed over the interests of established local people, whose rights are either ignored or construed by a supportive state as invalid. Conservation zones that fall short of strict protection, nonetheless represent a form of 'green grabbing' or accumulation by dispossession, imposing conservation practices on residents and opening up nature to new economic actors (e.g. ecotourist companies, Benjaminsen and Bryceson 2012, Bluwstein et al. 2018). However, the designation of farmed land for conservation may not require either the acquisition of formal property rights or physical eviction. Instead, control over land may be obtained by administrative means, in ‘dispossession by formalization’ Bluwstein et al. (2018). The development of wildlife management areas (WMAs) in rural Tanzania was a key element in the neoliberalization of the wildlife sector, enabling local level actors (including elites) to secure benefits from wildlife management (Green and Adams 2015, Bluwstein 2018). In the Rufiji Delta in Tanzania, Beymer-Farris and Bassett (2011) argue that a REDD+ project run by the Worldwide Fund for Nature caused the displacement of local communities from mangrove forests, although contest this assertion (Burgess et al. 2013).

Conservation land claims are made possible through a series of rhetorical strategies. First, the idea of 'community conservation' frames negotiations over resource management by local communities, often offering some element of devolution of rights and autonomy of governance in exchange for state-moderated constraints on how land and wildlife on it may be used (Goldman 2003, Sachedina and Nelson 2010, Greiner 2012). The outcome of land claims within National Parks in South Africa has led to co-management agreements with conservation authorities, which restrict land use to those compatible with conservation (e.g. through 'public-private partnerships' with wildlife tourism contractors (Kepe 2008). The trade-offs are such that these 'comanagement' outcomes are rarely compatible with conservation, land restitution or poverty alleviation goals.

A second rhetorical device concerns the notion of 'ecological corridors' (Goldman (2009), an ecological idea about the importance of landscape connectivity and longdistance movement to the maintenance of viable populations of large mammals, often reflecting a limited understand of land use and rights. In East Africa, ambitious land 
zonation is justified by the seasonal movements of large mammals, or of elephants between reserves and farms (e.g. Evans and Adams 2016, Green et al. 2018). Thus, in southern Tanzania, conservation planners identified a 'Selous-Niassa Corridor' stretching from the Selous Game Reserve to the Niassa National Park in Mozambique. This new conservation zones imposed new boundaries and new rules on local people, requiring constant intervention in the form of mapping, demarcation, enforcement, capacity building, and education (Bluwstein and Lund 2018)

\section{Securing Spaces}

The fifth dimension of the creation of conservation territories that has commanded attention from human geographers is the way they are demarcated and the rules determined for human behaviour within them are enforced. Technologies (understood broadly) play a central role in both processes (c.f. Adams 2017).

Physical demarcation of conservation boundaries on the ground typically involves markers and fences, but demarcation is increasingly digital, backed by GIS systems and GPS locations to create and enforce virtual boundaries. Maps, and the centralized analysis of spatial digital data from multiple sensors and sources, underpin the enforcement of the boundaries of conservation spaces. Massé (2018) uses the concept of topography to explore the way multiple spaces of power combine to police conservation lands, protecting selected bodies (often charismatic rare species such as rhinos), and proscribing others (particularly poachers). The rise of airborne surveillance, particularly from fixed wing aircraft, helicopters and drones, has transformed the work of protected area rangers in South Africa, enabling essential ground patrols to be targeted rapidly and effectively to prevent border transgressions. Movement of rangers by air allows rapid deployment in remote areas. Such technologies reduce the frictions that limit the exercise of power, and have become central to securing conservation territories (Massé 2018).

It is primarily within recognized and official conservation territories that the ongoing struggle to protect biodiversity (the 'war on poaching', as Duffy $(2014,2016)$ describes it), is carried forwards. Many studies, particularly on South Africa, continue to explore the dimensions of 'green militarization' (Lunstrum 2014), 'green violence' (Büscher and Ramutsindela 2015), or 'green war' (Buscher and Fletcher 
2018). The protection and destruction of nature surprisingly often involves violence or is described in military metaphors terms (Campbell and Veríssimo 2015). There are important questions about when, and by whom, green violence might be legitimately exercised (Fletcher 2018).

Active armed engagement with poachers is widely seen in Europe and North America as a necessary and legitimate response to catastrophic population decline in key species in the face of rampant international ivory and rhino horn smuggling (a 'necessary evil', Buscher and Fletcher 2018). These campaigns are viscerally material, with many deaths among both poachers and conservation rangers. However, conflicts around conservation spaces are also being waged discursively. Online communities often express extreme opinions about the killing of wild animals (the cruelty and sacrilege of illegal killing) and advocate extreme violence against poachers (Lunstrum 2017).

The framing of poachers as a threat to national security (because they kill charismatic mammals that support nationally significant tourist industries) is seen to transform their activities in protected areas into a security threat. In the transfrontier Great Limpopo National Park (Mozambique, Zimbabwe and South Africa), the portrayal of rhino poachers as 'armed insurgents' revived apartheid and cold war tropes of racialised, politically threatening and politically-motivated trespassers, particularly among white South African staff of the South African Peace Parks Foundation (Lunstrum and Ybarra 2018). Similarly, in Cameroon, wildlife declines in the Waza National Park are blamed on the actions of Islamic terrorists of Boko Haram. However, there is no evidence of using ivory to subsidize their operations (an argument also used and refuted in East Africa also, see White 2014). The narrative of terrorist poachers allows the Cameroonian government to avoid addressing deep historically embedded reasons for both insecurity in northern Cameroon, and the decline of Waza's wildlife (Pennaz et al. 2018). The fact that poachers do not have a political agenda is irrelevant: their classification as insurgents and a threat to national security is 'discursively productive' Lunstrum and Ybarra $(2018,118)$.

Such framings not only serve to legitimize military-style field campaigns against armed poachers (including 'shoot to kill' practices), but they also contribute to 
renewed campaigns to displace people from protected areas and their immediate surroundings. In Guatamala's Maya Biosphere Reserve (created in 1990), security concerns about narcotics trafficking triggered a new round of resettlement. In the protected area (on the Mexican border) the removal of small farmers was seen to address both the problem of forest conservation and as part of the military 'war on drugs' (Lunstrum and Ybarra 2018).

\section{Imagined spaces}

As David Hughes (2005) argued, conservation makes space, scale and time.

Conservation's Lefebvrian enterprise of producing space involves a continuously evolving set of spatial practices, driven by hunger to secure territory for nonhuman lives. Old and new conservation territories are being set out on the ground and in an expanding spatial lexicon of zonation and landscape ecology (Zimmerer 2000). These zones and spaces are then subjected to management and control, often to the detriment of people living in or near them, or somehow cutting across the defined interests of conservation planners.

Conservation clearly has a predilection for coercive methods in the exercise of biopower, more so in the developing world (where it is relatively strong) rather than industrialized countries (where it finds itself weak, Sandbrook 2017). A key source of conservation power involves what Fletcher (2010) calls 'truth environmentality', the development and promulgation of ideas about nature and the human occupation of land. Thus Margulies and Karanth (2018) describe how conservation strategies in Bandipur National Park in Karnataka, India, draw on simplistic narratives of humanwildlife conflict that hide more fundamental problems caused by changes in the regional economy or park management itself. Conflicts between people over resources are only too easily redirected into discourses about conflicts between people and wildlife (c.f. Margulies 2018).

Bluwstein and Lund $(2018,453)$ see the designation and physical demarcation of land for conservation corridors in terms of a 'double territorialization - of landscape and of mind'. Physical processes of boundary-making (mapping, marking, the creation and enforcement of rules) are accompanied by the creation of conceptual frames that legitimise space as natural, or set aside for nature, where normal human activities are 
not appropriate or permitted. These frames are created through scientific reports and papers, maps, capacity building, education and sensitization (Bluwstein and Lund (2018). These contribute to environmental governance by establishing rules of behavior, and supporting various kinds of 'community' self-policing and self-control.

There are, of course, limits to the power of conservation to define the terms in which nature is understood. Technologies of measurement and control can be turned against dominant agencies in counter-mapping, challenging both the control of information and assumptions about the universality of scientific mapping (e.g. Harris and Hazen 2006, Cullen 2018). But such defensive strategies, such counter-claims to nature and land, are few and scattered.

Conservation's appetite for space is unstinted, even after a century of expansion, driven by the relentless erosion of nonhuman life by the working of the global economy. Spaces for nature expand and grow more diverse. They are starting to develop beyond the physical world, colonising virtual or digital spaces. Conservation spaces form powerful brands (e.g. Serengeti, Yellowstone, the Pantanal, even 'Africa' as a generic wilderness whole, epitomized by The Lion King and wilderness tourist brochures). Many protected areas have a powerful virtual life in wildlife films, conservation websites, and tourism websites. Conservation's dependence on such imagined spaces (and complicity with the creation, storage and representation of wildlife spectacle for commercial purposes, see Igoe 2010) drives an evolving political ecology of nature care. As an advertiser, if not a geographer, might say, 'watch this space'.

\section{Funding}

The author(s) received no financial support for the research, authorship, and/or publication of this article. 


\section{References}

Adams W M (2017) Geographies of Conservation II: Technology, Surveillance and Conservation by Algorithm. Progress in Human Geography https://doi.org/10.1177/0309132517740220

Adams W M, Hodge, I.D and Sandbrook L (2014) New Spaces for Nature: the reterritorialization of biodiversity conservation under neoliberalism in the UK. Transactions of the Institute of British Geographers 39: 574-588.

Adams W M, Hodge, I D, Macgregor N A and Sandbrook,L (2016) Creating restoration landscapes: partnerships in large-scale conservation in the UK. Ecology and Society 21 (3):1. [online] URL: http://www.ecologyandsociety.org/vol21/iss3/art1/.

Ansell D, Freudenberger N and Gibbons MP (2016) The cost-effectiveness of agrienvironment schemes for biodiversity conservation: a quantitative review. Agriculture, Ecosystems and Environment 225: 184-191.

Balmford, A. and Green R (2017) How to spare half a planet. Nature 552: 175.

Balmford A, Amano T, Bartlett H, Chadwick D, Collins A. Edwards D, Field R, Garnsworthy P, Green R, Smith P, Waters H, Whitmore A, Broom D, Chara J, Finch T, Garnett E, Gathorne-Hardy A, Hernandez-Medrano J, Herrero M, Hua F, Latawiec A, Misselbrook T, Phalan B, Simmons B, Takahashi T, Vause J, zu Ermgassen E and Eisner R (2018) The environmental costs and benefits of high-yield farming. Nature Sustainability 1: 477-485.

Beever EA, Bradford JB, Germino MJ, Mattsson BJ, Van der Burg M and Brunson, M (2014) Successes and challenges of 11 broad-extent conservation programs. Conservation Biology 28: 302-314.

Benjaminsen TA and Bryceson I (2012) Conservation, green/blue grabbing and accumulation by dispossession in Tanzania. Journal of Peasant Studies 39: $335-355$.

Beymer-Farris BA, Bassett TJ (2011) The REDD menace: resurgent protectionism in Tanzania's mangrove forests. Global Environmental Change 22: 332-341.

Blanchard L, Sandbrook C, Fisher J and Vira B (2016) Investigating consistency of a pro-market perspective amongst conservationists. Conservation and Society 14: $112-124$.

Bluwstein J (2018) Creating ecotourism territories: environmentalities in Tanzania's community-based conservation. Geoforum 83:101-113. 
Bluwstein J and Lund E (2018) Territoriality by conservation in the Selous-Niassa Corridor in Tanzania. World Development 101: 453-465.

Bluwstein J, Lund JF, Askew K, Stein H, Noe C, Odgaard R. Maganga F, and Engström L (2017) Between dependence and deprivation: The interlocking nature of land alienation in Tanzania. Journal of Agrarian Change 18: 806830.

Brockington D and Wilkie D (2015) Protected areas and poverty Philosophical Transactions of the Royal Society B 370: 20140271.

Buller H (2008) 'Safe from the wolf': biosecurity, biodiversity, and competing philosophies of nature. Environment and Planning A 40: 1583-1597.

Burgess ND, Mwakalila S, Munishi P, Pfeifer M, Willcock S, Shirima D, Hamidu S, Bulenga G B, Rubens J, Machano H and Marchant R (2013) REDD herrings or REDD menace: Response to Beymer-Farris and Bassett, Global Environmental Change 23: 1349-1354.

Büscher B and Ramutsindela M (2015) Green violence: rhino poaching and the war to save southern Africa's Peace Parks. African Affairs 115: 1-22.

Büscher, B (2013) Transforming the Frontier: Peace Parks and the politics of neoliberal conservation in southern Africa. Durham NC: Duke University Press.

Büscher B and Fletcher R (2018) Under pressure: conceptualising political ecologies of green wars. Conservation and Society 16: 105-113.

Büscher B, Fletcher R, Brockington D, Sandbrook C, Adams W M, Campbell L, Corson C, Dressler W, Duffy R, Gray N, Holmes G, Kelly A, Lunstrum E, Ramutsindela M and Shanker K, 2017 Half-Earth or Whole Earth? Radical ideas for conservation, and their implications. Oryx 51: 407-410.

Büscher B, Sullivan S, Neves K, Igoe J and Brockington D (2012) Towards a Synthesized Critique of Neoliberal Biodiversity Conservation. Capitalism, Nature Socialism 23: 4-30

Campbell B and Veríssimo D (2015) Black Stork Down: Military Discourses in Bird Conservation in Malta. Human Ecology 43: 79-92.

Crooks KR and Sanjayan M (eds) (2006) Connectivity Conservation. Cambridge: Cambridge University Press. 
Cullen A (2015) Making sense of claims across international divides: critical PGIS and mapping customary land in Timor-Leste. Australian Geographer 46: 473490.

da Fonseca GAB, Bruner A, Mittermeier RA, Alger K, Gascon C and Rice RE (2005) On defying nature's end: the case for landscape-scale conservation. The George Wright Forum 22: 46-60.

Dinerstein E, Olson D, Joshi A, Vynne C, Burgess ND, Wikramanayake E, Hahn N, Palminteri S, Hedao P, Noss R, Hansen M, Locke H, Ellis EC, Jones B, Barber CV, Hayes R, Kormos C, Martin V, Crist E, Sechrest W, Price L, Baillie JEM, Weeden D, Suckling K, Davis C, Sizer N, Moore R, Thau D, Birch T, Potapov P, Turubanova S, Tyukavina A, de Souza N, Pintea L, Brito JC, Llewellyn OA, Miller AG, Patzelt A, Ghazanfar SA, Timberlake J, Klöser H, Shennan-Farpón Y, Kindt R, Lillesø JB, van Breugel P, Graudal, L, Voge, M, Al-Shammari KF, Saleem M (2017) An Ecoregion-Based Approach to Protecting Half the Terrestrial Realm. Bioscience 67: 534-5

Dowie M (2009) Conservation Refugees: The Hundred-year Conflict Between Global Conservation and Native Peoples. Cambridge Mass: MIT Press,

Duffy R (2014) Waging a war to save biodiversity: the rise of militarised conservation. International Affairs 4: 819-384

Duffy R (2016) War, by Conservation. Geoforum 69: 238-248.

Eigenbrod, F, Clarke, D, Hill, C, and Osborne, P (2017) Scaling up from protected areas in England: The value of establishing large conservation areas. Biological Conservation, 279-287.

Evans LE and Adams WM (2018) Elephants as Actors in the Political Ecology of Human-Elephant Conflict. Transactions of the Institute of British Geographers 43: 630-645.

Fairhead,J, Leach M and Scoones I (2012) Green grabbing: a new appropriation of nature? Journal of Peasant Studies 39: 237-61.

Fairhead J, Leach M and Scoones I (eds) (2013) Green Grabbing: A New Appropriation of Nature. London: Routledge.

Fitzsimons, J and G Wescott 2007 Perceptions and attitudes of land managers in multi-reserve networks and the implications for conservation. Journal of Environmental Management 84: 38-48. 
Fitzsimons, J and G Wescott (2005) History and Attributes of Selected Australian Multi-tenure Reserve Networks. Australian Geographer 36:75-93

Fitzsimons J, Pulsford, I and Wescott G 2013 Linking Australia's landscapes: lessons and opportunities for large-scale conservation networks. Melbourne, Victoria: CSIRO Publishing.

Fletcher R (2010) Neoliberal environmentality: Towards a poststructuralist political ecology of the conservation debate. Conservation and Society 8:171-81

Fletcher R (2018) License to kill: contesting the legitimacy of green violence. Conservation and Society 16: 1471-156

Fox GR (2018) The 2017 shooting of Kuki Gallmann and the politics of conservation in northern Kenya. African Studies Review 61: 210-236.

Gallmann K (1991) I Dreamed of Africa. London: Penguin.

Garland, E (2008) The elephant in the room: confronting the colonial character of wildlife conservation in Africa. African Studies Review 51: 51-74.

Gaywood MJ (2017) Reintroducing the Eurasian beaver Castor fiber to Scotland. Mammal Review 48: 48-61.

Gissibl B, Hohler S and Kupper P (eds) (2012) Civilizing Nature: national parks in global historical perspective. Oxford: Berghahn Books.

Glass J, Price, MF Scott A, and Warren C (eds) (2013) Lairds, Land and Sustainability: Scottish perspectives on upland management. Edinburgh: Edinburgh University Press.

Goldman M (2003) Partitioned nature, privileged knowledge: community-based conservation in Tanzania. Development and Change 34: 833-862.

Goldman M (2009) Constructing connectivity: conservation corridors and conservation politics in East African rangelands. Annals of the Association of American Geographers 99: 335-359.

Green KE and Adams WM (2014) Green Grabbing and the Dynamics of Local Level Engagement with Neoliberalization in Tanzania's Wildlife Management Areas. Development and Change, 42: 97-117.

Green SE Davidson Z, Kaaria T and Doncaster CP (2018) Do wildlife corridors link or extend habitat? Insights from elephant use of a Kenyan wildlife corridor. African Journal of Ecology, https://doi.org/10.1111/aje.12541.

Greiner C (2012) Unexpected consequences: wildlife conservation and territorial conflict in northern Kenya. Human Ecology 40: 415-425. 
Harris LM and Hazen HD (2006) Power of maps: (counter) mapping for conservation. ACME: An International E-Journal for Critical Geographies 4: 99-130.

Hingston RWG (1931) Proposed British national parks for Africa. Geographical Journal 77: 401-28.

Hodge ID and Adams WM (2012) Neoliberalization, rural land trusts and institutional blending. Geoforum 43: 472-482.

Hodge ID and Adams WM (2014) 'Property institutions for rural land conservation: towards a post-neoliberal agenda' Journal of Rural Studies 36: 453-62.

Holmes G (2010) The Rich, the Powerful and the Endangered: Conservation Elites, Networks and the Dominican Republic Antipode 42: 624-646.

Holmes G (2012) Biodiversity for Billionaires: Capitalism, Conservation and the Role of Philanthropy in Saving/Selling Nature. Development and Change 43(1), pp. $185-203$

Holmes G (2014) What is a land grab? Exploring green grabs, conservation, and private protected areas in southern Chile. Journal of Peasant Studies 41: 547567

Holmes G (2015) Markets, nature, neoliberalism and conservation through private protected areas in southern Chile. Environment and Planning A 47:850-866

Holmes, G (2012) Biodiversity for billionaires: capitalism, conservation and the role of philanthropy in saving/selling nature. Development and Change 43: 185203.

Holmes, G, Sandbrook, C and Fisher, J.A, 2017 Understanding conservationists' perspectives on the new-conservation debate Conservation Biology 31: 353363.

Hughes DM (2005) Third Nature: making space and time in the Great Limpopo Conservation Area. Cultural Anthropology 20: 157-184.

Igoe, $\mathrm{J}$ (2010) The spectacle of nature in the global economy of appearances: Anthropological engagements with the spectacular mediations of transnational conservation. Critique of Anthropology 30: 375-397

Igoe J, Neves K, Brockington D (2010) A spectacular eco-tour around the historic bloc: theorising the convergence of biodiversity conservation and capitalist expansion. Antipode 42: 486-512

Jacoby K 2001 Crimes Against Nature: Squatters, Poachers, Thieves, and the Hidden History of American Conservation. Berkeley: California University Press. 
Jones, K (2012) Unpacking Yellowstone: The American national park in global perspective. In: Gissibl, B, Hohler, S and Kupper, P (eds) Civilizing Nature: national parks in global historical perspective. Oxford: Berghahn Books, pp $31-49$.

Jørgensen, D. 2015 Rethinking Rewilding. Geoforum 65: 482-88.

Kamal S, Grodzinska-Jurczak M and Kaszynska AP (2015) Challenges and opportunities in biodiversity conservation on private land: an institutional perspective from Central Europe and North America. Biodiversity and Conservation 24: 1271-1292.

Kay K (2016) Breaking the bundle of rights: Conservation easements and the legal geographies of individuating nature. Environment and Planning A: Economy and Space 48: 504-522

Kepe, T (2008) Land claims and comanagement of protected areas in South Africa: exploring the challenges. Environmental Management 41: 311-321

Kiesecker J, Comendant T, Grandmason T, Gray E, Hall C, Hilsenbeck R, Kareiva P, Lozier L, Naehu P, Rissman A, Shaw R, and Zankel M (2007) Conservation Easements in Context: A quantitative analysis of their use by The Nature Conservancy. Frontiers in Ecology and the Environment, 5: 125-130

King B and Wilcox S (2008) Peace Parks and jaguar trails: transboundary conservation in a globalizing world. GeoJournal 71: 221-231.

Kupper P (2012) Translating Yellowstone: early European national parks, Weltnaturschutz and the Swiss model. In: Gissibl, B, Hohler, S and Kupper, P (eds) Civilizing Nature: national parks in global historical perspective.

Oxford: Berghahn Books, pp. 123-139.

Lindsey PA, Havemann CP, Lines RM, Price, AE, Retief, TA, Rhebergen T, Van der Waal, C and Romanach,S.S (2013) Benefits of wildlife-based land uses on private lands in Namibia and limitations affecting their development. Oryx 47: 41-53.

Logan S and Wekerle GR, 2008 Neoliberalizing environmental governance? Land trusts, private conservation and nature on the Oak Ridges Moraine. Geoforum, 39: 2097-2108.

López-Bao JV, Bruskotter J, and Chapron G (2017) Finding space for large carnivores. Nature Ecology \& Evolution 1, article no. 0140. 
Lorimer J, Sandom C, Jepson P, Doughty C, Barua M, and Kirby KJ (2015)

Rewilding: science, practice, and politics. Annual Review of Environment And Resources 40: 39-62.

Lunstrum E (2014) Green militarization: anti-poaching efforts and the spatial contours of Kruger National Park. Annals of the Association of American Geographers 104: 816-832.

Lunstrum E (2017) Feed them to the lions: Conservation violence goes online. Geoforum 79: 134-143

Lunstrum E, and Ybarra M (2018) Deploying Difference: Security Threat Narratives and State Displacement from Protected Areas. Conservation and Society 16: 114-124.

Lunstrum E (2013) Articulated sovereignty: extending Mozambican state power through the Great Limpopo Transfrontier Park. Political Geography 36: 1-11.

Mace GM, Barrett M, Burgess ND, Cornell SE, Freeman R, Grooten M and Purvis A 2018 Aiming higher to bend the curve of biodiversity loss. Nature Sustainability DOI: 10.1038/s41893-018-0130-0

Margulies JD (2018) The conservation ideological state apparatus. Conservation and Society 16: 181-192.

Margulies JD and Karanth KK (2018) The production of human-wildlife conflict: A political animal geography of encounter. Geoforum 95: 153-164.

Massé F (2018) Topographies of security and the multiple spatialities of (conservation) power: verticality, surveillance, and space-time compression in the bush. Political Geography 67: 56-64.

Mbaria, J and Ogada, M (2017) The Big Conservation Lie. Seattle: Lens and Pens.

Monbiot, G (2013) Feral: Searching for Enchantment on the Frontiers of Rewilding. Penguin: London.

Nature Needs Half (2019) History. https://natureneedshalf.org/who-we-are/history/, accessed 20 February 2019.

Navarro LM, and Pereira HM (2012) Rewilding abandoned landscapes in Europe. Ecosystems 15: 900-912.

Neumann RP (2004) Nature-state-territory: towards a critical theorization of conservation enclosures. In: Peet, R. and Watts M (eds) Liberation ecologies: environment, development, social movements. London: Routledge, pp. 195217. 
Noss R, Dobson AP, Baldwin R, Beier P, Davis CR, Dellasala DA, Francis J, Locke H, Nowak K, Lopez R, Reining C, Trombulak SC and Tabor G (2012) Bolder thinking for conservation. Conservation Biology 26: 1-4.

Oldekop JA, Holmes G, Harris WE, Evans KL (2016) A global assessment of the social and conservation outcomes of protected areas. Conservation Biology 30: 133-141.

Pasquini L, Fitzsimons J.A, Cowell S, Brandon K and Wescott G (2011) The establishment of large private nature reserves by conservation NGOs: key factors for successful implementation. Oryx 45: 373-380.

Pennaz AK, Ahmadou M, Moritz M and Scholte P (2018) Not Seeing the Cattle for the Elephants: The Implications of Discursive Linkages between Boko Haram and Wildlife Poaching in Waza. Conservation and Society 16: 125-135.

Pettorelli N, Barlow J, Stephens PA, Durant SM, Conor B, Schulte to Bühne, H, Sandom CJ, Wentworth J and du Toit JT (2017) Making rewilding fit for policy. Journal of Applied Ecology 55: 1114-1125.

Phalan B, Green RE, Dicks LV, Dotta G, Feniuk C, Lamb A, Strassburg BBN, Williams DR, zu Ermgassen EKHJ and Balmford A 2016 How can higheryield farming help to spare nature? Science 351: 450-451.

Radford J (2014) The role of private conservation in saving biodiversity in Australia. Ecological Management and Restoration 15: 2-3.

Ramutsindela M, Spierenburg M and Wels H (2011) Sponsoring Nature: Environmental Philanthropy for Conservation. London: Earthscan.

Ranger T (1999) Voices from the Rocks: nature, culture and history in the Matopos Hills of Zimbabwe. Oxford: James Currey.

Reynolds F (2017) The Fight for Beauty: our path to a better future. London: OneWorld.

Runte A (1987) National Parks: the American experience. Lincoln, Nebraska: University of Nebraska Press.

Sachedina H and Nelson F (2010) Protected areas and community incentives in savannah ecosystems: A case study of Tanzania's Maasai Steppe Oryx 44: 390-398.

Sandbrook C (2017) Weak yet strong: The uneven power relations of conservation. Oryx, 51: 379-380.

Sheail J (2010) Nature's spectacle: the world's first national parks and protected 
places. London: Earthscan.

Sorice MG, Haider W, Conner JR, Ditton RB (2011) Incentive structure of and private landowner participation in an endangered species conservation program. Conservation Biology 25: 587-596.

Stolton S, Redford KH, and Dudley N (2014) The Futures of Privately Protected Areas. Gland, Switzerland: IUCN.

Suzuki Y (2001) Drifting rhinos and fluid properties: the turn to wildlife production in Western Zimbabwe. Journal of Agrarian Change 1: 600-625.

Tree I (2018) Wilding: the return of nature to a British farm. London: Picador. Tunbridge JE (1978) Conservation trusts as geographical agents': their impact upon landscape, townscape and land use. Transactions of the Institute of British Geographers 6: 103-25.

UNEP-WCMC, IUCN and NGS (2018) Protected Planet Report 2018, UNEP-World Conservation Centre, IUCN and National Geographic Society, Cambridge UK; Gland, Switzerland; and Washington, D.C, USA

van der Windt H (2012) Parks without Wilderness, Wilderness without Parks? Assigning National Park status to Dutch Man-made Landscapes and Colonial Game Reserves. In: Gissibl, B, Hohler, S and Kupper, P (eds) Civilizing Nature: national parks in global historical perspective, Oxford: Berghahn Books, pp. 206-223.

Wakild, E (2012) ‘A Revolutionary Civilization: National Parks, Transnational Exchanges, and the Construction of Modern Mexico. In: Gissibl, B, Hohler, S and Kupper, P (eds.) Civilizing Nature: national parks in global historical perspective. Oxford: Berghahn Books, pp. 191-205.

Watson JEM, Venter O, Lee J, Jones KR, Possingham HP and Allan JR (2018) Protect the last of the wild. Nature 563:27-30.

White, C (2012) Revolution on the Range: The Rise of a New Ranch in the American West, Island Press, Washington.

White N (2014) The 'white gold of jihad': violence, legitimisation and contestation in anti-poaching strategies, Journal of Political Ecology, 21: 453-474.

Wilson EO (2016) Half-Earth:OurPlanet's Fight for Life. Liveright Publishing: London.

Wolmer W (2007) From Wilderness Vision to Farm Invasions: conservation and development in Zimbabwe's south-east lowveld. Oxford: James Currey. 
Wuerthner G, Crist E and Butler T (eds) (2015) Protecting the Wild Parks and Wilderness, The Foundation for Conservation. Washington DC: Island Press.

Wynne-Jones S, Strouts G, and Holmes G (2018) Abandoning of Reimagining a Cultural Heartland? Understanding and Responding to Rewilding Conflicts in Wales - the Case of the Cambrian Wildwood. Environmental Values 27: $377-$ 403.

Zimmerer K (2000) The reworking of conservation geographies: non-equilibrium landscapes and nature-society hybrids. Annals of the Association of American Geographers 99: 356-369.

Zimmerer, KS (2006) (ed.) Globalization and New Geographies of Conservation. Chicago: University of Chicago Press. 